\title{
РЕТРОСПЕКТИВА ПОГЛЯДІВ ФІЛОСОФІВ НА ФЕНОМЕН «СВІТОБАЧЕННЯ»
}

У статті розкривається семантика та історико-філософська еволючія поняття «світобачення» в прачях філософів різних епох: Г. Гегеля, Й. Гете, В. Дільтея, І. Канта, Л. фон Ранке, Ф. Шлейєрмахера, Ф. Шеллінга, К. Яспера та інших. Розглянуто історію виникнення слова «світобачення», розуміння та трактування означеного феномену у витоках європейської філософської думки. Розкриті підходи до розуміння поняття та його структурних складників різними філософськими школами. Встановлено, шо світобачення є багатогранним феноменом, $і$ ие зумовлює проблему його класифікаиії та структуризаиії. Запропоновано ретроспективний погляд на диференціацію поняття «світобачення» та «філософія» від гомерівських часів до сьогодення. Проведено хронологічну паралель у використанні поняття «світобачення» у європейському середовищі та на теренах украӥноросійськомовного простору. Розкрито специифіку основних категорій світобачення - «світ» та «людина», крім того, встановлено, щзо світобачення залежить від епохи, історичних подій, менталітету народу, сочіальних груп, організацій та низки супутніх аспектів. Зроблено акиент на передумові виникнення слова «світобачення» в украӥнській мові - слово «світогляд»; разом із тим зазначено відмінність двох понять, які мають спільнокореневу першу частину. Розглянуто праці українських науковців-філософів, які тим чи іншим чином торкалися проблеми світобачення, серед яких Д. Чижевський та В. Шинкарук. Узагальнено погляди науковців на феномен «світобачення»: незважаючи на те, щзо слово «світобачення» було «сконструйоване» у ХVІІІ столітті, світоглядні погляди виникли з появою людини та змінювались у процесі ї̈ еволюиійного становлення. Актуалізовано увагу на потребі звернення до першоджерел, витоків слова задля достовірного розуміння сутності означеного феномену.

Ключові слова: світобачення, ретроспектива поглядів, філософія.

Olha BOBYR,
orcid.org/0000-0002-2563-7011
Postgraduate Student at the Department of Innovative Technologies
in Pedagogy, Psychology and Social Work
Alfred Nobel University
(Dnipro, Ukraine) bobyrolga@gmail.com

\section{THE RETROSPECT OF THE PHILOSOPHERS' VIEWS ON THE PHENOMENON "MINDSET"}

The article reveals the semantics and the historico-philosophical evolution of the concept of 'mindset' in the works of philosophers of different epochs: G. Hegel, J. Goethe, W. Dilthey, I. Kant, L. von Ranke, F. Schleiermacher, F. Schelling, $K$. Jaspers and others. It studies the history of the origin of the word 'mindset', understanding and interpretation of this phenomenon in the origins of European philosophical thought. The paper reveals the approaches to understanding this concept and its structural components by various philosophical schools. It is defined that the mindset is a multifaceted phenomenon and this causes the problem of its classification and structuring. The retrospective view on the differentiation of the concepts of 'mindset' and 'philosophy' from Homeric times to the present is proposed. The chronological parallel was made in the use of the concept of 'mindset' in the European environment and in the Ukrainian-Russian-speaking space. It revealed the specifics of the main categories of mindset - 'world' and 'man'. In addition, it is established that the mindset depends on the epoch, historical events, the people's mentality, social groups, organizations and a number of related aspects. Special emphasis was placed on the preconditions for the emergence of the word 'mindset'in the Ukrainian language - the word 'worldview'; however, is noted the difference of two concepts which have a common root. In the article are considered works of Ukrainian philosophers who in one way or another touched on the problem of mindset, including D. Chizhevsky and V. Shinkaruk. Furthermore, the study generalizes views of scientists on the phenomenon of 'mindset': despite the fact that the word 'mindset' was 'constructed' in the XVIII century, worldviews emerged with the advent of man and changed in the process of its evolutionary formation. In the paper actualized attention to the need for recourse to primary sources and to the word origins for a reliable understanding of the essence of this phenomenon.

Key words: mindset, retrospect of the views, philosophy. 
Постановка проблеми. У структурі свідомості людини центральною категорією є світобачення, яке розвивається від народження й збагачується протягом усього життя. Питання формування світобачення сьогодні стає невід'ємною темою дисертаційних досліджень, особливо в становленні майбутніх фахівців мистецьких спеціальностей. Тому для кращого розуміння процесу його формування необхідно звернутися до аналізу витоків означеного поняття та iï семантики у працях філософів.

Аналіз досліджень. На сучасному етапі розвитку вітчизняної та зарубіжної науки багато вчених і досі розглядають питання сутності світобачення. Так, Б. Шулиндіна, С. Гусєва, Л. Курбатова розглядають сутність, структуру, методологію форм та типів світобачення, а також роль світоглядних ідеалів і установок у життєдіяльності людини. Ряд учених (О. Спіркін, І. Кон, О. Уледова) розглядають світобачення як поєднання психологічних $\mathrm{i}$ соціальних факторів життя. Крім того, філософські та психологічні аспекти світобачення досліджували такі вчені: Р. Арцішевский, Т. Бачинський, В. Коробка, В. Овчінніков, П. Рабінович, С. Сливка та інші.

Мета статті - вивчення та аналіз поглядів філософів на феномен «світобачення» в хронологічному порядку.

Виклад основного матеріалу. Ретельно вивчаючи проблему виникнення феномену «світобачення», дослідники філософської думки виділяють два підходи, які аргументовані в наукових працях. Одні науковці стверджують (Бибихин, 1995: 136-137), що термін вперше використав кенігсбергський філософ Іммануїл Кант у кінці XVIII століття, поєднавши два німецьких слова: «welt» - «світ» та «anschauung» - «погляд, споглядання», тобто «погляд на Всесвіт», а саме новоутворене слово прихильники цього підходу зустрічають у його роботі 1790 року «Критика здатності судження», яка присвячена естетиці й теології.

Відзначаючи складність життєвих процесів, I. Кант стверджував, що формування світобачення пов'язане з питанням «Що є людина?», на яке сама людина в процесі філософських роздумів, що будуть основані на теоретичних знаннях та життєвому досвіді, спробує дати відповідь для розуміння своєї суті; причому попередньо повинні бути відповіді на три інші питання: «Що я можу знати?», «Що я маю робити?» та «На що я можу сподіватися?» (Кант, 2000). У своїх роздумах філософ дійшов висновку, що «якщо існує наука, яка дійсно потрібна людині, то це та, яка дає їй можливість знати, яким чином зайняти своє місце у світі та правильно зрозуміти, яким треба бути, щоб бути людиною» (Кант, 1964: 204).

Акцентуючи увагу на другому підході, більшість науковців (Черноволенко, 1970: 22) стверджують, що перше джерело, в якому було використане поняття «світобачення», - робота німецького філософа Фрідріха Шлейєрмахера «Промови про релігію» 1799 року. Зазначена робота написана на дев'ять років пізніше, ніж кантівська, проте саме в ній дослідники вбачають звернення до внутрішнього світу людини як підгрунтя для формування світобачення, оскільки Ф. Шлейєрмахер розглядав процеси самопізнання та самоспоглядання як головні складники в процесі формування світобачення. До того жсамопізнання та самоспоглядання, як одні зі структурних елементів особистості 3 точки зору психології, є основою для професійного самовдосконалення, що особливо необхідно в становленні творчої особистості художника.

Зазначимо, що того ж 1799 року представник німецької класичної школи Фрідріх Шеллінг у роботі «Вступ до нарису системи натурфілософії» використав кантівське «Вельтаншаунг»; проте філософ надав йому нового трактування - самостійний та свідомий спосіб осягнення й пояснення цілісності існування. Цікавоюєдумка Ф. Шеллінга, що процес формування світобачення - це схема, яка не потребує теоретичного роз'яснення; причому він прив'язує цей процес до інтелігенції (лат. «intellegentia»- «мислячий, розумний, тямущий»), яку вважає несвідомо продуктивною саме у світобаченні, а свідомо - у створенні ідеального світу.

Один із засновників німецької класичної філософії Георг Гегель продовжив аналіз поняття «світобачення〉 як одного з ключових у філософії. Науковці підкреслюють, що саме Г. Гегель спробував створити універсальну теорію світобачення, виокремивши різні його типи: поняття «морального світобачення» зустрічаємо в роботі «Феноменологія духа» (Hegel, 1987), яке винесене в заголовок (нім. «Die moralische Weltanschauung»), а «релігійне» та «теоретичне» - у праці «Лекції з естетики». Цікавою для нас виявилась думка Г. Гегеля щодо теоретичного світобачення, оскільки філософ уважав його необхідним саме для характеристики ідейної позиції художника. Додамо, що про релігійне світобачення писав Л. фон Ранке, тоді як Й. Гете досліджував поетичне бачення світу.

Щодо подальшого аналізу поняття «світобачення», як зазначає М. Колесников (Колесников, 2010), послідовники ідей Гегеля почали розглядати його як синонім поняття «філософія», що $\epsilon$ систематизованим раціональним уявленням про буття природи та людини. 
Слід зауважити, що ідея єдності понять «світобачення» та «філософія» проіснувала недовго, оскільки вже у XIX столітті розпочинаються дискусії щодо такої синонімічності. Так, німецький історик культури та філософ-ідеаліст Вільгельм Дільтей наголошував, що «знання життя» вкрай відрізняється від «наукового знання» (Дильтей, 1995: 217-218). Він започаткував «закон утворення світобачення», який зводився до того, що світобачення розвивається на основі настрою, який виражає безліч відтінків та ставлень людини до світу (Дильтей, 1995: 219-220). Цікавим є факт, що В. Дільтей виділяв три типи світобачення: релігія, мистецтво та метафізика. Ним була запропонована думка, що відношення до надчутливого означає в релігії те ж саме, що і символ у мистецтві або ж поняття в метафізиці.

Німецький психолог і філософ Карл Ясперс у роботі «Психологія світобачення» говорив про те, що життєвою необхідністю людини є потреба в стійкому світобаченні, оскільки саме воно впорядковує життєвий досвід (Jaspers, 1954). Крім того, вчений стверджував, що світогляд окремих індивідів та соціальних груп тяжіє до гармонійного й оптимістичного в одних життєвих ситуаціях, а в інших - до похмурого та песимістичного сприйняття буття.

Узагальнивши наукові знання, М. Колесников (Колесников, 2010) роз'яснює, що в західній філософії виділяють два підходи до розуміння суті світобачення. У центрі уваги одного $\epsilon$ суб'єктивний підхід особистості, другого зовнішні об'єктивні основи.

Тоді як активне використання терміна «світобачення» в Європі розпочинається вже 3 другої половини XIX століття, в словниках російської мови воно навіть не згадується аж до кінця того ж століття. I лише на початку XX століття стає популярним російський переклад німецького слова «weltanschauung»- «світобачення».

Деякі вчені припускають, що ще учасники гуртка «Любомудри» (1823-1825 рр.) використовували німецьке «weltanschauung», проте в значенні «світоспоглядання», яке в російському філософському лексиконі затвердилось тільки в 30-40-х роках XIX століття, втім аж до початку $\mathrm{XX}$ століття не користувалось особливою популярністю (Константинова, 1995).

Існує думка, що вперше слово «світобачення» саме як науковий термін у російськомовному просторі використав академік Володимир Вернадський у 1902 році в статті «Про науковий світогляд» (Вернадский, 1902), зміст якої склали перші три лекції з курсу «Нариси з історії сучасного науко- вого світобачення», які науковець читав у Московському університеті того ж року. Вчений зазначав, що наукове світобачення розглядає не окремі сторони реальності, а дає уявлення про світ у цілому. В. Вернадський був переконаний, що світобачення $\epsilon$ досить мінливим, і поряд із науковим завжди стоїть філософське: «Філософське світобачення, писав В. Вернадський, - загалом і безпосередньо створює те середовище, в якому має місце і розвивається наукова думка» (Вернадский, 1988: 36).

Серед російських філософів «срібного століття» (межа XIX - XX ст.) значну увагу питанню світобачення приділили $\mathrm{H}$. Лоський у роботі 1931 року «Типи світобачення» та С. Франк у праці 1922 року «Вступ до філософії в стислому викладі» (Франк, 1993), в якій він зазначав, що сама філософія і $\epsilon$ цілісним світобаченням.

У радянський період поняття «світобачення» було пов'язане з формуванням нової національної ідеї, де головна роль відводилась суспільно-політичним та соціально-економічним факторам. Проте вже у 60-70-ті роки XX століття починає активно розвиватися особистісно орієнтоване направлення в трактуванні поняття «світобачення». У працях О. Спіркіна, I. Кона, О. Уледова та багатьох їхніх сучасників світобачення розглядається як поєднання внутрішніх (психологічних) та зовнішніх (соціальних) факторів життя. Спираючись на такий синтез факторів, О. Спіркін виводить нове тлумачення даного поняття, як «системи поглядів людини і суспільства на світ загалом, на своє власне місце в ньому; розуміння й оцінки людиною сенсу свого життя та діяльності» (Спиркин, 2006: 15).

Плідним для дослідження сутності поняття «світобачення» був період «перебудови» (1985-1991 рр.) та «постперебудови», коли ідеологічний тиск партійних і державних органів зменшився, а серед науковців знову з'явився інтерес до вивчення світобачення як особливого духовного складника. Серед наукових здобутків 3 теми, яка нами розглядається, слід акцентувати увагу на докторській дисертації Б. Шулиндіна «Методологічні основи світоглядного діалогу в умовах сучасного суспільства», на роботі С. Гусєва «Буденне світобачення. Структура і способи організації» та дослідженні Л. Курбатової «Світобачення як фактор діяльної сутності людини», які розглядали сутність, структуру, методологію форм та типів світобачення, а також роль світоглядних ідеалів і установок в життєдіяльності людини.

В україномовному дискурсі вперше 3'явилося са́ме слово «світогляд» у назві твору I. НечуяЛевицького «Світогляд українського народу», який був надрукований у львівській «Правді» 
31868 по 1876 роки, і де письменник виклав свій досвід осягнення світогляду рідної нації та співвідношення в ньому народних традицій і віри 3 наукою та історією.

Вже у XX столітті український учений Дмитро Чижевський у своїх працях «Філософія на Україні (спроба історіографії)» та «Нариси 3 історії філософії на Україні» намагався знайти «українські» риси у філософів, при цьому співвідносив їх з ознаками національного світогляду. I серед типових представників національного українського характеру в галузі філософії він виділяв Г. Сковороду, М. Гоголя та П. Юркевича (Чижевський, 2005: 14). Ще в одній грунтовній роботі Д. Чижевський відокремив поняття «світогляд» від філософського знання, стверджуючи, що світогляд є певним поглядом на світ, але він не повинен бути обгрунтованим, а філософія, на його думку, і $є$ системою певних поглядів, які основані на аргументах і доказах. Для нього філософія - «мислення в поняттях», а світогляд - зібрання думок, уявлень та фантазій (Чижевський, 1994: 6).

Серед українських науковців-філософів, які тим чи іншим чином торкалися проблеми світобачення - представники Київського світоглядноантропологічного напряму. Так, академік В. Шин- карук зазначав, що світогляд - це історична форма суспільної самосвідомості людини, через яку сприймається, осмислюється та оцінюється навколишнє середовище, а також своє відношення до світу і визначення свого місця в ньому. На противагу Д. Чижевському, В. Шинкарук вважав, що філософія - це не лише теоретичне обгрунтування, але й вона спрямована на становлення внутрішнього людського мислення (Шинкарук, 1991).

Аналіз філософських досліджень 3 означеної проблеми показав, що питання історико-філософської еволюції поняття «світобачення» бере свій початок ще за часів Гомера, проте основу та варіації його семантики активно обгрунтовували у XIX столітті.

Висновки. Попередньо викладений матеріал стосувався семантики самого слова «світобачення», яке було «сконструйоване» у XVIII столітті, проте на практиці світоглядні погляди виникали 3 появою людини та змінювались у процесі ii еволюційного становлення; отже, значною когортою вітчизняних та зарубіжних науковців зроблено грунтовне дослідження процесу змін у світобаченні людства від первісного суспільства й до нашого сьогодення і визначено, що фундаментальними категоріями світобачення $\epsilon$ категорії «світ» та «людина».

\section{СПИСОК ВИКОРИСТАНИХ ДЖЕРЕЛ}

1. Бибихин В. В. Мир. Томск : Водолей, 1995. 144 с.

2. Вернадский В. И. О научном мировоззрении. Вопросы философии и психологии. Москва, 1902. С. 1408-1465.

3. Вернадский В. И. Философские мысли натуралиста. Москва : Наука, 1988. 522 с.

4. Дильтей У. Типы мировоззрения и обнаружение их в метафизических системах. Культурология. ХХ век : Антология. Москва : Юрист, 1995. 703 с.

5. Кант I. Критика чистого розуму. Філософія : Хрестоматія / упоряд. І. Демчик. Кам'янець-Подільський : Абетка, 2000. C. 94-102.

6. Кант И. Приложение к «Наблюдениям над чувством прекрасного и возвышенного». Москва, 1964. Т. 2. С. 204.

7. Колесников М. А. Философское понятие «мировоззрение»: исторический анализ эволюции. Преподаватель ХХІ век. 2010. № 4. С. 222-227.

8. Константинова Л. В. Общество любомудрия (1820-е-начало 1830-х гг.) : автореферат дис. ... ; Моск. пед. гос. ун-т. Москва, 1995. 16 с.

9. Спиркин А. Г. Философия : учебник. Москва : Гардарики, 2006. 736 с.

10. Франк С. Л. Введение в философию в сжатом изложении. Санкт-Петербург : Абрис-книга, 1993. 96 с.

11. Черноволенко В. Ф. Мировоззрение и научное познание. Киев : изд-во Киевского ун-та, 1970. 174 с.

12. Чижевський Д. Антична філософія в конспективному вигляді. Кіровоград, 1994. 72 с.

13. Чижевський Д. Нариси з історії філософії на Україні : філософські твори у чотирьох томах. Київ : Смолоскип, 2005. Т. 1. С. $1-162$.

14. Шинкарук В. І. Філософія і нові історичні реалії. 1991. № 1. С. 4-8.

15. Jaspers K. Psychologie der Weltanschauungen. Berlin : Springer, 1954. 352 p.

16. Hegel G. W. F. Phänomenologie des Geistes. Stuttgart : Philipp Reclam jun. 1987. 596 p.

\section{REFERENCES}

1. Bibihin V. V. Mir. [The world]. Tomsk: Vodolej, 1995. 144 p. [in Russian].

2. Vernadskij V. I. O nauchnom mirovozzrenii. Voprosy filosofii i psihologii. [On the scientific worldview. Questions of philosophy and psychology]. Moskva, 1902. pp. 1408-1465. [in Russian].

3. Vernadskij V. I. Filosofskie mysli naturalista. [Philosophical thoughts of a naturalist]. Moskva: Nauka, 1988. 522 p. [in Russian].

4. Dil'tej U. Tipy mirovozzreniya i obnaruzhenie ih v metafizicheskih sistemah. [Types of worldview and their detection in metaphysical systems]. Kul'turologiya. XX vek: Antologiya. Moskva: Yurist, 1995. 703 p. [in Russian]. 
5. Kant I. Kritika chistogo rozumu. Filosofiya: Hrestomatiya. Uporyad. I. Demchik. [Criticism of pure rosumu. Philosophy: Reader]. Kam'yanec'-Podil's'kij: Abetka, 2000. pp. 94-102. [in Ukrainian].

6. Kant I. Prilozhenie k «Nablyudeniyam nad chuvstvom prekrasnogo i vozvyshennogo». [Appendix to «Observations on the Sense of Beauty and the Sublime»]. Moskva, 1964. t. 2. P. 204. [in Russian].

7. Kolesnikov M. A. Filosofskoe ponyatie «mirovozzrenie»: istoricheskij analiz evolyucii. [The philosophical concept of «worldview»: a historical analysis of evolution]. Prepodavatel XXI vek. 2010. № 4. P. 222-227. [in Russian].

8. Konstantinova L. V. Obshchestvo lyubomudriya (1820-e-nachalo 1830-h gg.): avtoreferat dis. [Society of Wisdom]. Mosk. ped. gos. un-t. Moskva, 1995. 16 p. [in Russian].

9. Spirkin A. G. Filosofiya: Uchebnik. [Philosophy: Textbook]. Moskva: Gardariki, 2006. 736 p. [in Russian].

10. Frank S. L. Vvedenii v filosofiyu v szhatom izlozhenii. [Concise introduction to philosophy]. SPB: Abris-kniga, 1993. 96 p. [in Russian].

11. CHernovolenko V. F. Mirovozzrenie i nauchnoe poznanie. [Worldview and scientific knowledge]. Kiev: izd-vo Kievskogo un-ta, 1970. 174 p. [in Russian].

12. CHizhevs'kij D. Antichna filosofiya v konspektivnomu viglyadi. [Antique philosophy in synopsis]. Kirovograd, 1994. 72 p. [in Ukrainian].

13. CHizhevs'kij D. Narisi z istoriï filosofiï na Ukraïni. Filosofs'ki tvori u chotir'oh tomah. [Essays with the history of philosophy in Ukraine. Philosophical works in four volumes]. Kiïv : Smoloskip, 2005. T.1. P.1-162. [in Ukrainian].

14. SHinkaruk V. I. Filosofiya i novi istorichni realiï. [Philosophy and new historical realities]. 1991. №1. P. 4-8. [in Ukrainian].

15. Jaspers K. Psychologie der Weltanschauungen. Berlin: Springer, 1954. 352 p.

16. Hegel G. W. F. Phänomenologie des Geistes. Stuttgart: Philipp Reclam jun. 1987. 596 p. 